\title{
Світлана КОВАЛЬ
}

\section{СИСТЕМА ДЕРЖАВНОГО СОЦІАМЬНОГО СТРАХУВАННЯ: ДОСВІД УКРӒ̈НИ ТА НІМЕЧЧИНИ}

\begin{abstract}
Розглянуто підходи до трактування соціального страхування: як системи економічних відносин, як елемента соціальної політики держави, як складової соціального захисту населення. Здійснено порівняльний аналіз форм соціального страхування і джерел фрінансування виплат в Україні та Німеччині. Досліджено практичні аспекти фуннкіонування обов'язкового медичного страхування у Німеччині, виявлено позитивні його риси. Запропоновано до впровадження в Україні прогресивного досвіду Німеччини, спрямованого на покращення ситуації у сфрері охорони здоров'я.
\end{abstract}

Ключові слова: державне соціальне страхування, пенсійне страхування, страхування у зв'язку з тимчасовою втратою працездатності, медичне страхування, страхування від нещасного випадку на виробництві та професійного захворювання, страхування на випадок безробіття.

\section{Светлана КОВАЛЬ}

Система государственного социального страхования: опыт Украины и Германии

Рассмотрены подходы к трактовке социального страхования как системы экономических отношений, как элемента социальной политики государства, как составляющей социальной защиты населения. Осуществлен сравнительный анализ форм социального страхования и источников финансирования выплат Украины и Германии. Исследованы практические аспекты функционирования обязательного медицинского страхования в Германии, выявлены положительные его черты. Предложен к внедрению в Украине прогрессивный опыт Германии, направленный на улучшение ситуации в сорере здравоохранения.

Ключевые слова: государственное социальное страхование, пенсионное страхование, страхование в связи с временной потерей трудоспособности, медицинское страхование, страхование от несчастного случая на производстве и профессионального заболевания, страхование на случай безработицы.

\section{Svitlana KOVAL}

\section{System of state social insurance: experience of Ukraine and Germany}

Introduction. Social protection of the population is one of the state functions The implementation of a socially oriented state policy involves solving the problems of social protection and is aimed at creating the proper conditions for a decent standard of living and free development of the individual.

(c) Світлана Коваль, 2018 
The emergence and functioning of social insurance is conditioned by the presence of various social risks and the need to retain citizens who can not take an active part in the process of social production.

Purpose. The purpose of the article is to study the practical principles of the functioning of the system of state social insurance of Ukraine and Germany and to develop, on this basis, practical recommendations aimed at improving the social insurance of Ukraine in the context of the borrowing of progressive experience in Germany.

Results. Approaches to the treatment of social insurance are considered: as a system of economic relations, as an element of the social policy of the state, as a component of social protection of the population. A comparative analysis of forms of social insurance and sources of financing payments in Ukraine and Germany has been carried out. The practical aspects of functioning of compulsory medical insurance in Germany are investigated, its positive features are revealed.

Conclusion. It is revealed that the forms and sources of state social insurance of Ukraine and Germany are similar. The exception is the state health insurance, which in Ukraine is in the stage of implementation.

The necessity to restore the payment of a single social contribution by hired workers in the conditions of a shortage of financial resources in the sphere of social insurance of Ukraine is substantiated.

It is proposed to apply in the domestic practice the mechanism of functioning of the state medical insurance of Germany, which excludes the possibility of abuses by medical workers in the context of the appointment of unnecessary medical examinations and procedures.

Keywords: state social insurance, pension insurance, temporary incapacity insurance, health insurance, industrial accident and occupational accident insurance, unemployment insurance.

JEL Classification: G230, H550.

Постановка проблеми. Однією із функцій держави $є$ забезпечення соціального захисту населення. Реалізація соціально орієнтованої політики держави передбачає вирішення проблем соціального захисту громадян і спрямована на створення умов для належного рівня життя та вільного розвитку особистості.

Загальнообов'язкове державне соціальне страхування $€$ важливою складовою системи соціального захисту населення і відіграє значну роль у житті громадян будьякої країни, особливо тих, які втратили можливість забезпечувати себе самостійно. Виникнення та функціонування соціального страхування зумовлене наявністю різноманітних соціальних ризиків та необхідністю утримання громадян, які не можуть брати активної участі в процесі суспільного виробництва.

Аналіз останніх досліджень і публікацій. Вагомий внесок у формування теоретичних і практичних засад соціального страхування зробили такі зарубіжні науковці, як: У. Беверідж, О. фрон Бісмарк, Р. Ноузік, Дж. Ролз й ін. На особливу увагу заслуговують праці українських вчених: Г. Єфремової, О. Кириленко, А. Кириченка, Е. Лібанової, М. Мальованого, В. Надраги, Б. Надточія, В. Плиси, М. Ріппи, А. Сидор- 
чука, В. Толуб'яка, О. Тулай, М. Шавариної, Н. Шаманської, С. Юрія та ін.

Дослідження наукових джерел дало можливість дійти висновку, що державне соціальне страхування $є$ складною, багатогранною категорією. Так, укладачі фрінансово-економічного словника А. Загородній та Г. Вознюк під державним соціальним страхуванням розуміють гарантовану державою систему заходів, спрямованих на забезпечення громадян у старості, у випадку захворювання або втрати працездатності, підтримання материнства і дитинства, охорони здоров'я та як спосіб реалізації конституційного права громадян [1, с. 885].

Економічна енциклопедія трактує державне соціальне страхування як систему економічних відносин, за допомогою яких формують та використовують фонди грошових коштів, які передбачені для матеріального забезпечення непрацездатних осіб [2, с. 398].

Як систему відносин між застрахованою особою, страхувальником і страховиком, які передбачають надання застрахованій особі матеріального забезпечення у випадку хвороби, повної, часткової або тимчасової втрати працездатності, втрати годувальника, безробіття, старості за рахунок коштів соціальних страхових фондів, котрі формуються внаслідок сплати страхових внесків, трактує соціальне страхування В. Надрага [3, с. 100].

Заслуговує на увагу тлумачення соціального страхування, подане С. Юрієм, як сукупності економічних відносин, які виникають у процесі розподілу та перерозподілу ВВП і передбачають формування та використання фондів грошових коштів для забезпечення громадян у старості, на випадок постійної чи тимчасової втрати працездатності, безробіття, підтримки материнства, а також охорони здоров'я [4, с. 17].

Принципово інше бачення соціального страхування запропоновано В. Плисою.
Вчений розглядає соціальне страхування як важливий складовий елемент соціальної політики держави, який функціонує у сфері управління ризиками відтворення населення та виконує функцію соціального захисту, забезпечує фінансування соціальних допомог, регулює доходи та рівень життя різних груп населення, попереджує наслідки настання соціальних ризиків [5, с. 7]. Подібний підхід до тлумачення досліджуваного поняття пропонує Г. Єфремова. На думку вченої, соціальне страхування $€$ елементом соціальної політики, що реалізується у сфері управління ризиками відтворення населення і виявляється у процесі надання застрахованим особам матеріального забезпечення у випадку хвороби, у разі настання повної чи тимчасової втрати працездатності, втрати годувальника, безробіття, при досягненні похилого віку та в інших випадках, передбачених законодавством за рахунок державних соціальних страхових фондів, сформованих у процесі сплати страхових внесків [6, с. 257].

Автори посібника "Соціальне страхування" визначають досліджуване поняття як складову соціального захисту населення, у центрі якого - людина і її потреби [7, с. 24]. Близьке за змістом трактування запропоновано М. Мальованим - це форма соціального захисту, яка дає можливість дотриматись необхідних стандартів рівня життя у разі настання соціальних ризиків [8, с. 14].

Незважаючи на наявність вагомих теоретичних досліджень, у практичній площині функціонування державного соціального страхування накопичилось багато проблем, які негативно відображаються на соціальноекономічному розвитку країни, добробуті, зайнятості громадян, забезпеченні виконання соціальної функції держави. Зміна економічної ситуації, інтеграція України у світове співтовариство вимагають значних структурних перетворень у системі соціального захисту 
населення загалом та загальнообов'язкового державного соціального страхування зокрема. 3 огляду на це, комплексне дослідження питань, пов'язаних із функціонуванням системи загальнообов'язкового державного соціального страхування та вивчення прогресивного досвіду Німеччини, набуває особливої актуальності.

Метою статті $€$ висвітлення практичних засад функціонування системи державного соціального страхування України і Німеччини та вироблення на цій основі практичних рекомендацій, спрямованих на удосконалення соціального страхування України в контексті запозичення прогресивного досвіду Німеччини.

Виклад основного матеріалу дослідження. Конституцією проголошено Україну як соціальну державу, соціальна політика якої має бути спрямована на створення умов для достойного рівня життя і вільного розвитку особистості. Зокрема, статтею $46 \mathrm{Koн-}$ ституції України закріплено право громадян на соціальний захист, що включає право на забезпечення їх у разі повної, часткової або тимчасової втрати працездатності, втрати годувальника, безробіття із незалежних від них обставин, у старості та в інших випадках [9].

Відповідно до “Основ законодавства України про загальнообов'язкове державне соціальне страхування" передбачено такі його види:

- пенсійне страхування;
- страхування у зв'язку з тимчасовою втратою працездатності;

- медичне страхування;

- страхування від нещасного випадку на виробництві та професійного захворювання, які спричинили втрату працездатності;

- страхування на випадок безробіття [10]. Медичне страхування, хоча і передбачено законодавством, наразі не фуннкціонує. До 2015 р. виплати 3 системи загальнообов'язкового державного соціального страхування здійснювались із: Пенсійного фонду України, Фонду загальнообов'язкового державного страхування на випадок безробіття, Фонду загальнообов'язкового державного соціального страхування на випадок тимчасової втрати працездатності, Фонду загальнообов'язкового державного соціального страхування від нещасних випадків на виробництві та професійних захворювань, які спричинили втрату працездатності. В результаті реформування цих структур створено Фонд соціального страхування України (табл. 1).

Основним джерелом формування доходів бюджетів фондів соціального страхування є обов'язкові внески. До 2011 р. доходи бюджетів фондів соціального страхування України переважно формувались за рахунок страхових внесків, які нараховували на загальний фонд оплати праці відповідно до встановленого для кожного

Таблиця 1

Форми державного соціального страхування України та джерела фінансування виплат*

\begin{tabular}{|l||l||}
\hline \multicolumn{1}{|c||}{ Форми соціального страхування } & \multicolumn{1}{|c||}{ Джерело фінансування } \\
\hline \hline пенсійне страхування & Пенсійний фонд України \\
\hline \hline страхування у зв'язку з тимчасовою втратою працездатності & Фонд соціального страхування \\
\hline \hline $\begin{array}{l}\text { страхування від нещасного випадку на виробництві та професій- } \\
\text { ного захворювання, які спричинили втрату працездатності }\end{array}$ & Країни \\
\hline \hline страхування на випадок безробіття & $\begin{array}{l}\text { Фонд соціального страхування } \\
\text { на випадок безробіття }\end{array}$ \\
\hline
\end{tabular}

* Узагальнено та складено автором. 
із фондів страхового тарифу і сплачували страхувальники-роботодавці та застраховані особи (наймані працівники).

Починаючи з 2011 р., запроваджено сплату єдиного соціального внеску [11]. Крім того, починаючи із 2016 р. наймані працівники не сплачують єдиний внесок на загальнообов'язкове державне соціальне страхування.

Німеччина $є$ високорозвиненою країною Європейського Союзу, яка за багатовікову історію накопичила значний досвід у сфері державного соціального страхування. Вивчення тенденцій та характерних рис державного соціального страхування в цій державі викликає особливий інтерес, оскільки дасть можливість запозичити досвід для впровадження в Україні.

Основи обов'язкового державного соціального страхування Німеччини започатковано ще наприкінці XIX ст., коли було вперше прийнято законодавчі акти, які стосувалися соціального захисту громадян. Розвитку системи соціального страхування сприяв канцлер Німеччини Отто фон Бісмарк, заслугою якого було те, що у 1883-1889 рр. уперше у законодавчому порядку запроваджено державну систему соціального страхування. Так, у 1883 р. набув чинності закон про обов'язкове державне страхування на випадок хвороби, у 1884 р. - закон про страхування від нещасних випадків на виробництві [12, с. 164].

Ще у 1825 р. у Німеччині було створено перший пенсійний фонд, однак застрахованими особами були лише чиновники. В результаті активних заходів з боку канцлера Отто фон Бісмарка у 1889 р. вперше у світовій практиці була запроваджена система державного пенсійного страхування. За його ініціативи у 1889 р. ухвалили закон про страхування на випадок інвалідності і старості, котрий передбачав охоплення всіх робітників та службовців, які мали річ- ний дохід до 2000 рейхсмарок і гарантовано можливість виходу на пенсію у 70 років. Така система пенсійного страхування забезпечувала однакові умови для всіх працюючих: чоловіків і жінок, робітників і державних службовців [12, с. 165].

Система державного соціального страхування, запроваджена Отто фон Бісмарком, заснована на таких принципах:

- поширення страхових виплат лише на тих осіб, які отримали це право завдяки своїй праці;

- надання страхових виплат лише тим найманим працівникам, чия заробітна плата була нижчою за встановлену законодавчо мінімальну суму;

- встановлення фіксованого співвідношення страхових внесків, які сплачували роботодавці та працівники;

- орієнтованість на управління системою соціального страхування як з боку найманих працівників, так і роботодавців $[13$, c. 30$]$.

Найбільшим здобутком Бісмарка вчені вважають запровадження обов'язковості системи соціального страхування. Така модель мала велике значення не лише для Німеччини, а й для інших країн, котрі з часом також використали цей досвід.

Нині у Німеччині функціонує п'ять форм державного соціального страхування, які регламентуються Кодексом соціального права:

- державне медичне страхування;

- державне обов'язкове страхування у разі догляду за хворою чи старою людиною;

- державне пенсійне страхування;

- державне страхування на випадок безробіття;

- державне страхування від наслідків нещасного випадку на виробництві (табл. 2).

У межах функціонування державної системи соціального страхування всі ро- 
ботодавці укладають з найманими працівниками соціальні страхові договори. Розмір страхових внесків залежить від обсягу зарплати найманого працівника. Страхові внески сплачують у рівних пропорціях працівник та роботодавець. Винятком $€$ внески на страхування від наслідків нещасного випадку на виробництві, найманий працівник не несе жодних витрат, страхові внески в повному обсязі сплачує роботодавець. Як бачимо, фрорми державного соціального страхування України та Німеччини $є$ ідентичними.

Фінансова база системи державного соціального страхування в Україні та Німеч- чині фрормується за рахунок обов'язкових страхових внесків (табл. 3).

Рівень внесків на соціальне страхування в Україні був дещо вищим, порівняно з Німеччиною, у 2008-2015 рр. Разом з тим, починаючи з 2016 р. в Україні ставка ЄСВ для роботодавців була знижена, а найманих працівників звільнено від сплати ЄСВ.

Зважаючи на історичний досвід функціонування соціального страхування у Німеччині, який є одним із найкращих у Європі, доцільно запроваджувати його у практику України.

Так, державне медичне страхування в Україні поки що перебуває лише на стадії

\section{Форми державного соціального страхування Німеччини та джерела фрінансування виплат*}

\begin{tabular}{|c|c|}
\hline Форми & Джерело фінансування \\
\hline державне медичне страхування & \multirow[b]{2}{*}{ державна медична каса } \\
\hline $\begin{array}{l}\text { державне обов'язкове страхування у разі догляду за } \\
\text { хворою чи старою людиною }\end{array}$ & \\
\hline державне пенсійне страхування & земельне або фредеральне страхове товариство \\
\hline державне страхування на випадок безробіття & федеральне відомство праці \\
\hline $\begin{array}{l}\text { державне страхування від наслідків нещасного ви- } \\
\text { падку на виробництві }\end{array}$ & $\begin{array}{l}\text { союз підприємців однієї чи спорідненої галузі } \\
\text { промисловості }\end{array}$ \\
\hline
\end{tabular}

* Узагальнено та складено автором

\begin{tabular}{|c|c|c|c|c|c|}
\hline \multicolumn{5}{|c|}{$\begin{array}{c}\text { Страхове навантаження в системі соціального страхування } \\
\text { в Німеччині та Україні, \% }[14, \text { с. 47] }\end{array}$} & Таблиця 3 \\
\hline \multirow{2}{*}{ Показники } & \multicolumn{5}{|c|}{ Період } \\
\hline & 2008 & 2012 & 2014 & 2015 & 2016 \\
\hline \multicolumn{6}{|c|}{ Німеччина } \\
\hline Страхові внески, всього сплачені в т. ч. & 39,91 & 40,08 & 39,46 & 39,56 & 39,76 \\
\hline роботодавцем & 19,5 & 19,6 & 19,28 & 19,33 & 19,33 \\
\hline працівником & 20,41 & 20,48 & 20,18 & 20,23 & 20,43 \\
\hline \multicolumn{6}{|c|}{ Україна } \\
\hline Страхові внески, всього сплачені в т. ч. & 49,7 & 53,3 & 53,3 & 53,3 & 22 \\
\hline роботодавцем & 49,7 & 49,7 & 49,7 & 49,7 & 22 \\
\hline працівником & 0 & 3,6 & 3,6 & 3,6 & 0 \\
\hline
\end{tabular}


запровадження. Обов'язкове соціальне медичне страхування Німеччини, гарантує застрахованому найманому працівнику та членам його сім'ї збереження звичного рівня життя. Активними суб'єктами державного медичного страхування є незалежні організації - лікарняні каси та асоціації лікарів. Обов'язкові внески сплачують як роботодавці, так і наймані працівники. Управління лікарняними касами здійснюють збори представників, які складаються із представників роботодавців (50\%) та найманих працівників (50\%). Розмір обов'язкових внесків визначають на загальних зборах, він становить близько 13\% від фонду оплати праці.

Принципи, на яких базується обов'язкове соціальне медичне страхування у Німеччині, подано на рис. 3.

Обов'язкове соціальне медичне страхування Німеччини передбачає: покриття матеріальних витрат, пов'язаних із діагностикою і профілактикою захворювань; лікування в амбулаторних і стаціонарних медичних закладах; придбання ліків і допоміжних засобів при амбулаторному та стаціонарному лікуванні. Крім того, цей вид соціального страхування передбачає виплату допомоги у зв'язку із тимчасовою втратою працездатності.

Федеральним законодавством передбачено передачу землям (всього 16 федеральних земель) відповідальності за організацію медичної допомоги на місцях. Так, кожна земля має забезпечити фінансування лікарень та гарантувати задоволення потреб населення у медичних послугах. На рівні земель існує власне законодавство у сорері надання медичних послуг, яке враховує специфіку регіону, рівень його соціально-економічного розвитку, що зумовлює певні відмінності у характері, межах та методах реалізації медичних програм у різних регіонах [16, с. 122].

Фінансування системи охорони здоров'я Німеччини переважно здійснюється за рахунок коштів державного медичного страхування (57\%) - Gesetzliche Krankenversicherung. Причому саме ним охоплено близько 90\% населення. Інші громадяни або є учасниками недержавного страхування, або застраховані в межах інших спеціальних державних програм (військовослужбовці, поліцейські, отримувачі соціальних виплат тощо).

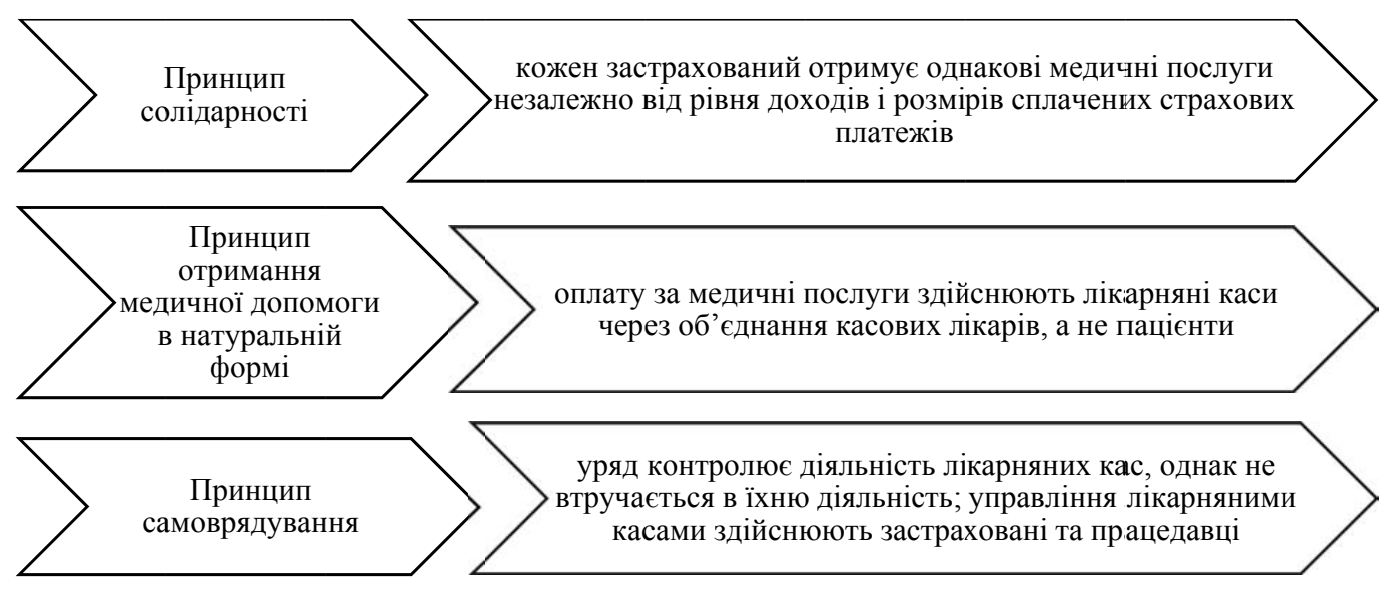

Рис. 3. Принципи функціонування обов'язкового соціального

* Побудовано на основі [15, с. 244]. медичного страхування Німеччини* 
Основним джерелом фрінансування охорони здоров'я у Німеччині $є$ самоврядні регіональні і федеральні лікарняні каси (gesetzliche Krankenkassen), котрі мобілізують страхові внески і забезпечують фінансування медичних послуг в межах соціальних гарантій держави. Усі лікарняні каси $€$ некомерційними організаціями, на які покладено обов'язки збору страхових внесків. Крім того, їм законодавчо надано право встановлювати ставки страхових внесків для покриття необхідних витрат.

Особливістю системи державного медичного страхування Німеччини $є$ те, що страхові внески найманих працівників забезпечують не лише їх особисте страхування, а і членів їх сімей, які не працюють. При цьому жодних додаткових страхових внесків працівник не здійснює. Ще однією відмінністю страхових внесків державного медичного страхування у Німеччині $€$ те, що внески справляються не лише із заробітної плати, а й з пенсій, допомоги на випадок безробіття [16, с. 122].

Всі застраховані особи і члени їх сімей мають однакове право на медичні послуги незалежно від їх соціального стану, розмірів страхових внесків і тривалості страхування. До послуг, які надають у системі обов'язкового медичного страхування Німеччини, належать:

- профрілактика захворювань, охорона здоров'я на робочому місці;

- медичне обстеження для виявлення захворювань;

- лікування (амбулаторна та стоматологічна допомога, стаціонарне лікування, сестринський догляд удома, лікарські засоби, послуги спеціалістів суміжних із медициною професій, окремі види реабілітації, соціальна терапія);

- невідкладна допомога, транспортування хворих у важких станах;
- надання інформаційних послуг [16, с. 123].

Досвід Німеччини стосовно оплати праці лікарів, на нашу думку, може бути застосованим в Україні. Система медичного страхування Німеччини дає змогу виключати можливість зловживань із боку медичних працівників у контексті призначень непотрібних медичних обстежень та процедур. Страхові організації здійснюють оплату наданих медичних послуг на основі бальної системи оцінки рівня наданих послуг. Бали встановлюють у розрізі наданих послуг. Розмір плати медичним працівникам розраховують на підставі отриманих ними балів як співвідношення загальної кількості балів, зароблених усіма лікарями, і регіонального бюджету охорони здоров'я. Такий спосіб обчислення вартості передбачає, що збільшення обсягу наданих медичних послуг у регіоні призводить до того, що кожен бал буде мати меншу цінність.

3 метою обмеження можливостей лікарів в отриманні більших доходів шляхом необґрунтованого включення до звітів більшого обсягу наданих послуг, комітети лікарів і фондів охорони здоров'я здійснюють постійний нагляд за діяльністю медичних установ, і будь-яке відхилення звітності від реального обсягу наданих медичних послуг відображається у статистичних спостереженнях за медичною установою і дає можливість виявити лікаря, показники якого істотно відхиляються від середніх показників $[17$, c. 14$]$.

На нашу думку, у побудові страхової моделі фінансового забезпечення охорони здоров'я в Україні доцільно врахувати ментальність українських громадян. Особливістю українців $є$ недостатньо відповідальне ставлення більшості населення до свого здоров'я, яке зумовлено незнанням вартості медичних послуг. А це зумовлює неправильну поведінку особи, коли застра- 
хований не має стимулу берегти здоров'я, запобігати його погіршенню і раціонально використовувати послуги медичних закладів [18, с. 26].

Вивчення досвіду Німеччини у сфері державного медичного страхування дає можливість рекомендувати до застосування в Україні такі заходи:

- розробити та затвердити нормативнуправову базу, яка регулюватиме відносини у системі державного медичного страхування України;

- впровадити систему персоніфрікованого обліку та автоматичного звітування про надані медичні послуги;

- створити програмно-технічний комплекс державного медичного страхування.

Впровадження державного медичного страхування в Україні дасть можливість покращити ситуацію у сфері охорони здоров'я, оплачувати послуги медичних закладів відповідно до обсягу і якості наданих послуг, що сприятиме підвищенню оплати праці медичних працівників; забезпечити фрінансову незалежність лікувальних закладів; виключити можливість зловживань із боку медичних працівників у контексті призначень непотрібних медичних обстежень та процедур.

Висновки. Проведене дослідження практики функціонування державного соціального страхування в Україні та Німеччині дало змогу сформулювати такі висновки і пропозиції.

1. Форми та джерела державного соціального страхування України та Німеччини $€$ подібними. Винятком $є$ державне медичне страхування, яке в Україні перебуває на стадії впровадження.

2. Фінансовою базою державного соціального страхування України та Німеччини $€$ страхові внески, які у Німеччині сплачують як роботодавці, так і наймані працівни- ки, в Україні (починаючи із 2016 р.) - лише роботодавці.

В умовах дефіциту фінансових ресурсів у сфері соціального страхування України доцільно відновити сплату єдиного соціального внеску найманими працівниками.

3. Державне медичне страхування у Німеччині має понад столітню історію, а в Україні поки що не запроваджене. Високий рівень організації обов'язкового медичного страхування у Німеччині зумовлює доцільність запозичення ії̈ прогресивного досвіду.

4. Враховуючи, що механізм функціонування державного медичного страхування Німеччини виключає можливість зловживань із боку медичних працівників у контексті призначення непотрібних медичних обстежень та процедур, варто застосувати такий досвід у вітчизняну практику.

3 огляду на складність порушеної проблематики, наступні наукові розвідки необхідно здійснювати з метою пошуку ефективних джерел фінансового забезпечення вітчизняної системи соціального страхування в Україні.

\section{Список використаних джерел}

1. Загородній А.Г. Фінансово-економічний словник / А.Г. Загородній, Г.Л. Вознюк. - К. : Знання, 2007. - 1072 с.

2. Економічна енциклопедія : у 3 m. - Т. 3 / редкол. : С. В. Мочерний (відп. ред.) та ін. - К. : Видавничий центр “Академія", 2002. - 952 с.

3. Надрага В.І. Соціальне страхування в системі соціального регулювання ризиків / В.І. Надрага // Вісник економічної науки України. - 2014. № 2. - C. 99-103.

4. Юрій С.І. Соціальне страхування : підруч. / С.І. Юрій, М.П. Шаварина, Н.В. Шаманська. - К. : Кондор, 2004. - 464 c.

5. Плиса В.Й. Загальнообов'язкове державне соціальне страхування в Україні : навч. посіб. / В.Й. Плиса. - Львів : ВЦ ЛНУ ім. І. Франка, 2003. -160 c. 
6. Єфремова Г.В. Поняття і сутність загальнообов'язкового державного соціального страхування у зв'язку з тимчасовою втратою працездатності / Г.В. Єфремова // Форум права. - 2012. - № 2. - C. 256-260.

7. Соціальне страхування / за ред. О.П. КUриленко та В.С. Толуб'яка. - Тернопіль : ТНЕУ, 2016. - 516 c.

8. Мальований М.I. Соціальне страхування: навч. підруч. / М.І. Мальований, П.К. Бечко, В.П. Бечко. - Умань : Видавець “Сочінський”, 2011. $-476 \mathrm{c}$.

9. Конституція України від 28.06.1996 р. /в ред. від 28.06.2016 р. [Електронний ресурс]. Режим доступу : http://zakon2.rada.gov.ua/laws/ show/254\%D0\%BA/96-\%D0\%B2\%D1\%80.

10. Основи законодавства України про загальнообов'язкове державне соціальне страхування (1998р.) в ред. від 20.01.2018 р. [Електронний ресурс]. - Режим доступу : http://zakon3.rada.gov.ua/laws/show/16/98$\% D 0 \% B 2 \% D 1 \% 80$

11. Закон України “Про збір та облік єдиного внеску на загальнообов'язкове державне соціальне страхування" від 08.07.2010 p. № 2464 -V [Електронний ресурс]. - Режим доступу : http:// zakon3.rada.gov.ua/laws/show/2464-17

12. Ріппа М.Б. Еволюція пенсійного забезпечення Німеччини: від Бісмарка до Рістера / М.Б. Ріппа, Т.В. Тучак // Фінанси, облік і аудит. 2009. - № 14. - C. 161-171.

13. Надточій Б. Соціальне страхування у контексті історії / Б. Надточій // Соціальний захист. - 2003. - № 2. - C. 20-24.

14. Кириченко А.В. Розвиток соціального страхування в Україні : монографрія / А.В. Кириченко. - К. : ЦП “КОМПРИНТ”, 2017. - 197 с.

15. Тулай О.І. Державні фрінанси і сталий людський розвиток: концептуальні домінанти та діалектична єдність : монографія / O.I. Tyлай. - Тернопіль : ТНЕУ, 2016. - 415 c.

16. Стеценко В. Правове забезпечення обов'язкового медичного страхування в Німеччині (ключові засади та досвід для України) /
В. Стеценко // Вісник Академії управління МВС. 2010. - № 3(15). - C. 120-126.

17. Сасковеи А.А. Государственное медицинское страхование в Германии: становление, проблемы, стратегические решения / А.A. Сасковец. - М. : МАКС Пресс, 2005. - 28 с.

18. Юнусов Ф. Управление здравоохранением и организация медицинского страхования / Ф. Юнусов. - СПб. : ООО “Артиком”, 2007. - 296 с.

\section{References}

1. Zahorodnii, A. H., Vozniuk, H. L. (2007). Finansovo-ekonomichnyi slovnyk [The finance-economical dictionary]. Kyiv: Znannia [in Ukrainian].

2. Mochernyi, S.V. (Eds.). (2002). Ekonomichna entsyklopediia [Economical encyclopaedia]. (Vol. 3). Kyiv: Vydavnychyi tsentr "Akademiia" [in Ukrainian].

3. Nadraha, V.I. (2014). Sotsialne strakhuvannia $v$ systemi sotsialnoho rehuliuvannia ryzykiv [Social insurance in the system of social regulation of risks]. Visnyk ekonomichnoi nauky Ukrainy - Bulletin of economic science of Ukraine, 2, 99-103 [in Ukrainian].

4. Yurii, S.I., Shavaryna, M.P., Shamanska, N.V. (2004). Sotsialne strakhuvannia [Social insurance]. Kyiv: Kondor [in Ukrainian].

5. Plysa, V.Y. (2003). Zahalnooboviazkove derzhavne sotsialne strakhuvannia v Ukraini [Obligatory state social insurance in Ukraine]. Lviv: VTs LNU im. I. Franka [in Ukrainian].

6. Yefremova, H.V. (2012). Poniattia i sutnist zahalnooboviazkovoho derzhavnoho sotsialnoho strakhuvannia u zviazku z tymchasovoiu vtratoiu pratsezdatnosti [The concept and essence of compulsory state social insurance in connection with temporary disability]. Forum prava - Forum of rights, 2, 256-260 [in Ukrainian].

7. Kyrylenko, O.P. \& Tolubiak, V.S. (Eds.). (2016). Sotsialne strakhuvannia [Social insurance]. Ternopil: TNEU [in Ukrainian].

8. Malovanyi, M.I., Bechko, P.K., Bechko, V.P. (2011). Sotsialne strakhuvannia [Social insurance]. Uman: Vydavets "Sochinskyi" [in Ukrainian]. 


\section{БЮДЖЕТНА І ФІСКАЛЬНА ПОЛІТИКА}

9. Konstytutsiia Ukrainy vid 28.06.1996 r. $v$ red. vid 28.06.2016 r. [The Constitution of Ukraine]. (1996, June, 28). Available at: http:// zakon2.rada.gov.ua/laws/show/254\%D0\%BA/96$\% D 0 \% B 2 \% D 1 \% 80$.

10. Osnovy zakonodavstva Ukrainy pro zahalnooboviazkove derzhavne sotsialne strakhuvannia (1998 r.) v red. vid 20.01.2018 r. [Fundamentals of Ukrainian legislation on compulsory state social insurance]. Available at: http://zakon3.rada.gov.ua/ laws/show/16/98-\%D0\%B2\%D1\%80

11. Zakon Ukrainy "Pro zbir ta oblik yedynoho vnesku na zahalnooboviazkove derzhavne sotsialne strakhuvannia” vid 08.07.2010 r. № 2464-V [The Law of Ukraine "On the collection and accounting of the single contribution to the mandatory state social insurance"]. (2010, July, 08). Available at: http://zakon3.rada.gov.ua/laws/show/2464-17

12. Rippa, M.B., Tuchak, T.V. (2009). Evoliutsiia pensiinoho zabezpechennia Nimechchyny: vid Bismarka do Ristera [Evolution of pensions in Germany: from Bismarck to Rister]. Finansy, oblik $i$ audyt - Finance, accounting and audit, 14, 161-171 [in Ukrainian].

13. Nadtochii, B. (2003). Sotsialne strakhuvannia $u$ konteksti istorii [Social insurance in the context of history]. Sotsialnyi zakhyst - Social protection, 2, 20-24 [in Ukrainian].

14. Kyrychenko, A.V. (2017). Rozvytok sotsialnoho strakhuvannia $v$ Ukraini [Development of so- cial insurance in Ukraine]. Kyiv: TsP "KOMPRYNT" [in Ukrainian].

15. Tulai, O.I. (2016). Derzhavni finansy i stalyi liudskyi rozvytok: kontseptualni dominanty ta dialektychna yednist [Public finances and sustainable human development: conceptual dominant and dialectical unity]. Ternopil: TNEU [in Ukrainian].

16. Stetsenko V. (2010). Pravove zabezpechennia oboviazkovoho medychnoho strakhuvannia $v$ Nimechchyni (kliuchovi zasady ta dosvid dlia Ukrainy) [Legal framework for compulsory medical insurance in Germany (key principles and experience for Ukraine)]. Visnyk Akademii upravlinnia MVS - Bulletin of the Academy of the Ministry of Internal Affairs, 3(15), 120-126 [in Ukrainian].

17. Saskovets, A.A. (2005). Gosudarstvennoe meditsinskoe strahovanie v Germanii: stanovlenie, problemyi, strategicheskie resheniya [State health insurance in Germany: formation, problems, strategic decisions]. Moscow: MAKS Press [in Russian].

18. Yunusov, F. (2007). Upravlenie zdravoohraneniem $i$ organizatsiya meditsinskogo strahovaniya [Health management and organization of health insurance]. Saint Petersburg: OOO "Artikom" [in Russian].

Стаття надійшла до редакції 30.01.2018. 